\title{
Distal Bile Duct Cancer pT3 TNM Finding v8
}

National Cancer Institute

\section{Source}

National Cancer Institute. Distal Bile Duct CancerpT3 TNM Finding v8. NCI Thesaurus.

Code C134802.

Distal bile duct cancer with tumor invading the bile duct wall with a depth greater than 12 mm. (from AJCC 8th Ed.) 